\title{
大規模商業施設計画のための買い物行動モデル SHOPPING BEHAVIORAL MODEL FOR LARGE-SCALE COMMERCIAL FACILITIES PLANNING
}

\author{
長澤夏子*, 佐古 崇**, 渡辺仁史*** \\ Natsuko NAGASAWA, Takashi SAKO and Hitoshi WATANABE
}

\begin{abstract}
We investigated people in a large-scale, commercial facilities in Japan. As a result, it was clarified to be able to describe the shopping behavior in the following two states.

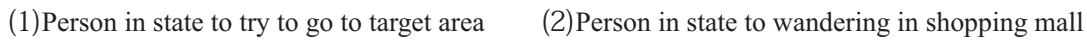

The person changes by two states and decides the route. This state variation and routing have been decided from the investigation according to acquired data. And, the space made a divergence part and a target store a network as a node. Finally, the simulation result showed good agreement with the result of the field survey. This model was able to reproduce the whole of the shopping behavior done in the shopping mall. This model can be used at the esquisse stage of architectural planning.
\end{abstract}

Keywords : Shopping mall, State transition, A human behavioral simulation, Architectural Planning 商業施設, 状態遷移, 人間行動シミュレーション，建築計画

\section{1. はじめに}

近年、各地で大型複合商業施設がオープンしている。一方でイン ターネットショッピングなど様々な買い物の形態が出現し、買い物 行動の特徴の二極化が進んでいると言われている。インターネット ショッピングなどに顕著な「効率性を求める行動」と、大型複合商 業施設などに代表される「体験性を求める行動」である。また、マ 一ケティングの分野で言われる「一人十色」という言葉にも見られ るように、一人の人間が状況によって何通りものライフスタイルを 同時に持つ時代であり、これまでのような年齢や性別などの属性と いった顧客類型化からの側面だけの行動予測では不十分であると言 われている。このような中で、大規模商業施設の建築計画時に、体 験重視型の買い物空間として適したプランニングを行い建物を提供 するためには、その行動特性に合致した施設である事が重要で、現 代的な買い物行動の挙動、および、それによっておこる館内の買い 物者の分布予測が不可欠である。

店舗内の日常的な買い物行動は、それぞれの買い物客がそれぞれ の目的を持って各店舗に向かっていたり、ウィンドーショッピング をして通路を順番に見ていたりと、経路の取り方もそれぞれの人の 状態によって異なる。またその状態も時系列的に変化し、行動も変
化してゆく。そのため、避難や初売り ${ }^{1)}$ などの単一目的的なケース と異なり、群衆流動的 ${ }^{2)}$ な扱いでは説明しきれない部分がある。館 内にいる買い物客全体について把握するには、このような個人個人 の状態とそれに応じた行動を含んだ集団として捉えることが必要で ある。

一方、これまでの商業施設における日常買い物客の行動のモデル 化に関する研究として、セルオートマトンを基礎としたシミュレー ションが挙げられる。阿部ら ${ }^{3)}$ は小売店鋪内での買い物客を計画購 買者と非計画購買者の二つの属性に分類し、商品や POP の魅力度を 設定しモデル化することで店舗内のレイアウトやPOP の配置によっ て買い物客の流れや店内滞在時間が変化する事を検証した。セルオ ートマトンモデルの多くは、周辺空間からの情報などに基づいて状 態の遷移や行動選択を行っており、対象空間が小売店鋪やスーパー の 1 フロアのように、一定規模でまとまったものについては有効で あった。しかし、対象空間が小売店鋪であるため店舗を買い回る時 に買い物客の目的状態遷移によって行動特性が変わるという視点は なく、また 1 フロアでのモデルが多く、大規模商業施設内での日常 的な買い物行動に関する予測を行うまでには至っていない。

デパートのような多層階の建物での客の行動は、一般に「シャワ

\footnotetext{
* 早稲田大学理工学術院総合研究所 次席研究員 ·博士 (工学)

** (株)松田平田設計

*** 早稲田大学理工学術院建築学科 教授.工博

Junior Researcher, Waseda Research Institute for Science and Engineering, Waseda Univ., Ph. D.

MHS Planners, Architects \& Engineers, M. Eng.

Prof., Faculty of Science and Eng., Waseda Univ., Dr. Eng.
} 


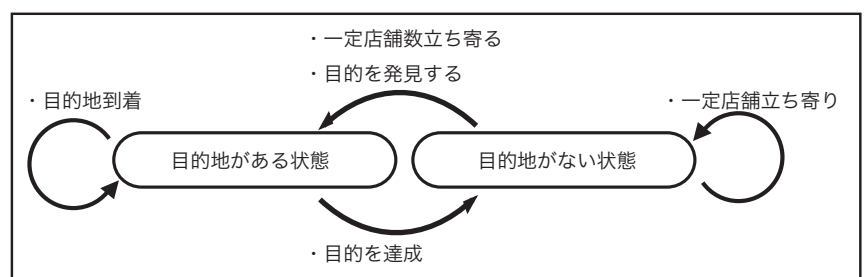

図 1 状態遷移のモデル

一効果」や「噴水効果」といわれるように、人気集客箇所と、そこ から一筆書きで全館回覧をしてくれることを期待している。しかし、 近年の客の行動の特徵として全館を見回っている数がどの程度いる のか、といった行動の基礎的なデータをとる必要がある。

\section{2. 研究目的}

本論は商業施設において買い物中の人を追跡調查して、施設内での 行動記録から、買い物行動をそれぞれの目的の状態と行動からその 特徵を明らかにする。それらの結果をもとにした買い物行動モデル とネットワーク型空間モデルを組み合わせて、時系列的に変化する 人々を再現するためのシミュレーションモデルを作成することが目 的である。これによって、設計初期段階のプランニングでも利用でき、 また大規模商業施設全体の構成や、垂直動線計画や計画案の行動効 果予測が可能なシステムの開発を目指す。

\section{3. 研究方法}

\section{1 語句の定義}

館内に多くの店舗がテナントとして入っているような商業施設を 想定し、客はこの中の特定の、あるいは特定でない店舗に立ち寄り ながら買物行動を行っている。そこで、それぞれの店舗、あるいは 店舗がまとまったゾーンを一つの単位として、それを目指して買い 物していることとする。その際の行動について、2つの行動状態想 定し、それらが遷移しながら現れるモデルを仮定した（図 1 ）。

目的地がある状態 : 客が自ら設定した次の目的地に向かっていく 行動をする状態。

目的地がない状態 : 特定目的商品を探しておらず、ちょうどウィ ンドーショッピングを行っている状態。

立ち寄り店舗 : 本研究では、購入の有無には関係なく、その店舗 に興味を示し、入店した店舗とする。

「目的地がある状態」では、周囲の店舗や商品に関心をあまり向け ておらず、行動も、目にとまる商品への興味や周辺店舗に影響を受 ける可能性が低い状態にあると考えられる。「目的地がない状態」で は、歩きながら周囲の店舗や商品へ意識を向け、行動が商品への興 味や周辺店舗などに影響を受ける可能性が高い状態にあると推察で きる。

\section{2 買い物行動追跡調査方法}

都内にある商業施設 3 店舗において、買い物客の行動追跡調查を 行った。概要は表 1 の通りである。無作為に追跡対象者を選定し注 1 、 対象者が入店してから退店するまでの間追跡を行った。

\section{4. 買い物行動の特性（調査結果）}

表 1 買い物行動追跡調査概要

\begin{tabular}{|c|c|c|}
\hline & 第1回調査 & 第2回調査 \\
\hline 調査日時 & $2007 / 6 / 22 \sim 7 / 6$ & $2007 / 10 / 4 \sim 10 / 15$ \\
\hline 調査場所 & 東京都商業施設3店舗 & 東京都商業施設 1 店舗 \\
\hline 調査人数 & 122名 & 57名 \\
\hline 調査項目 & \multicolumn{2}{|c|}{$\begin{array}{l}\text { 人数 } \\
\text { (グループであれば)グループの特性 } \\
\text { 年齢層 } \\
\text { 性別 } \\
\text { 時刻:各フロア·各店舗入店退店時間 } \\
\text { 歩行時の状態 } \\
\text { 歩行経路 }\end{array}$} \\
\hline
\end{tabular}

表 2 状態遷移確率表

\begin{tabular}{|c|c|c|}
\hline from $\quad$ to & 目的地ある状態 & 目的地ない状態 \\
\hline 目的地ある状態 & 0.620 & 0.380 \\
\hline 目的地ない状態 & 0.253 & 0.747 \\
\hline
\end{tabular}

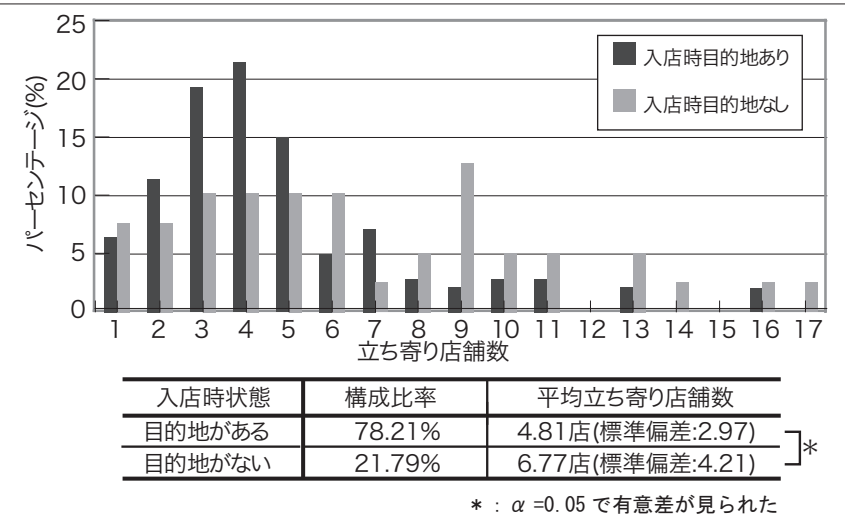

図 2 入店時状態と立ち寄り店舗数

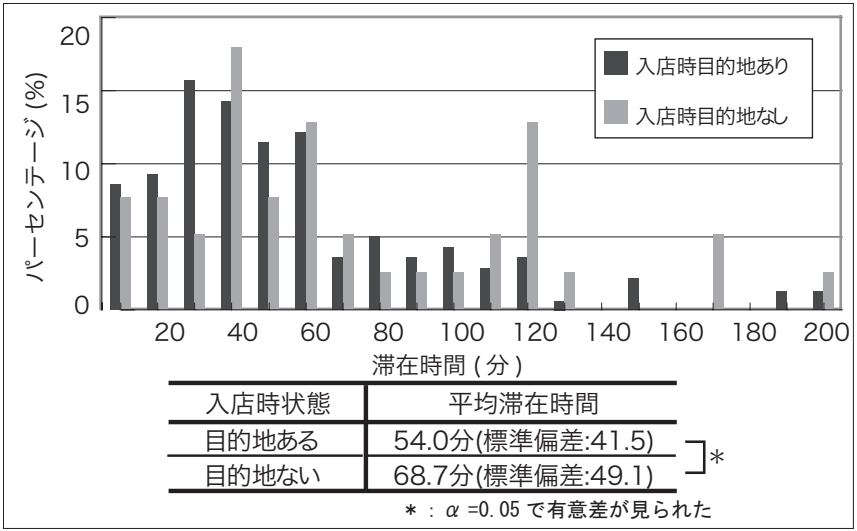

図 3 入店時状態と滞在時間

\section{1 状態遷移}

買い物客の買い物行動を 3 。で述べた二つの状態ととらえ、立ち 寄り店舗ごとに時刻や行動、対象者の状態を観察により判断して記 録し注 $2 、 そ の$ 出現回数から状態の遷移について状態遷移確率を求め たところ、表 2 のようになた。目的地のない状態から目的地のな い状態への遷移が多く見られ、一度目的地がない行動になるとその 状態が連続しやすいということが分かった。 


\section{2 入店時状態と立ち寄り店舗数}

買い物客の入店時の状態、つまり入店から最初の店舗までの状態を 「初期状態」とし集計を行った。初期状態と立ち寄り店舗数の関係が 図 2 である。初期状態が「目的地がある状態」は $78.2 \%$ 、「目的地 がない状態」は $21.8 \%$ であった。また平均立ち寄り店舗数は入店時 の状態が目的地がある状態のものは 4.81 店で目的地がない状態の ものは 6.77 店であった。初めから目的をもって来店しているもの の多くは、立ち寄り店舗数は少ない。来店時に目的がはっきりして いるものはそれのみを果たして退店するという行動が多いが、一方 で入店時に目的を持たないものは店舗内を回遊しながら、店舗に立 ち寄り、その中で時には目的を思いついたり、発見したりして店舗 に立ち寄るなどの行動を行っているためだと考えられる。このこと は滞在時間（図 3）にも現れており、入店時に目的地がない状態の ものは平均 68.7 分であり、目的地のある状態のものは平均 54.0 分 となっており、入店に目的地がないものの方が長い。

\section{3 状態別立ち寄り店舗間距離}

歩行経路において歩行時の状態、立ち寄った店舗と店舗の間の距離 を求め、その時の状態との関係を分析した。その結果各状態と距離 の関係は図 4 の通りになった。有意水準 $5 \%$ で立ち寄り店舗間距離 に有意差が見られた。また、相対的なばらつきを見るために変動係 数を求めた。目的地がある状態の時の方が立ち寄り店舗間距離が長 く、ばらつきが大きい。目的の買い物を果たすために距離には関係 なく移動するためであろう。一方目的地がない状態では、立ち寄る 店舗選択の理由として距離がより関係しており、近くの店舗に立ち 寄りや寸い事が考えられる。

\section{4 状態別フロア移動回数}

買い物客の各状態別にみたフロア移動回数をみた（図 5）目的地 がある状態では平均 1.49 回であり、目的地がない状態では平均 0.92 回であった。「目的地がない状態」では経路にそって近い店舗に次々 に入るような行動がみられ、そのために同一フロア移動がおおい結 果となった。本調査では複層階の建物での調査であったため、「目的 地のある状態」では、「目的地のない状態」に比べてフロア移動が多 くなる結果となった。

\section{5 状態別移動フロア数}

次に各状態時においてフロア移動を行った時の移動フロア数をみ た。結果は図 6 の通りである。目的地がある状態では平均 3.37 フロ アであり、目的地がない状態では平均 1.99 フロアであった。状態別 に検定を行ったところ有意水準 $5 \%$ での有意差が見られた。目的地 がない状態では $57.0 \%$ が 1 フロアのみの移動であり、隣のフロアを 非常に選択しや寸い特性がある事が分かった。

\section{6 買い物行動追跡調査のまとめ}

以上、目的地がある状態と目的地がない状態の 2 つで、行動特性に、 それぞれ違いがあることが明らかになった。

立ち寄る店舗に関しては、目的地がある状態の時は店舗間距離に 依存せずに目的店舗へ向かうが、目的地がない状態の時は近い店舗

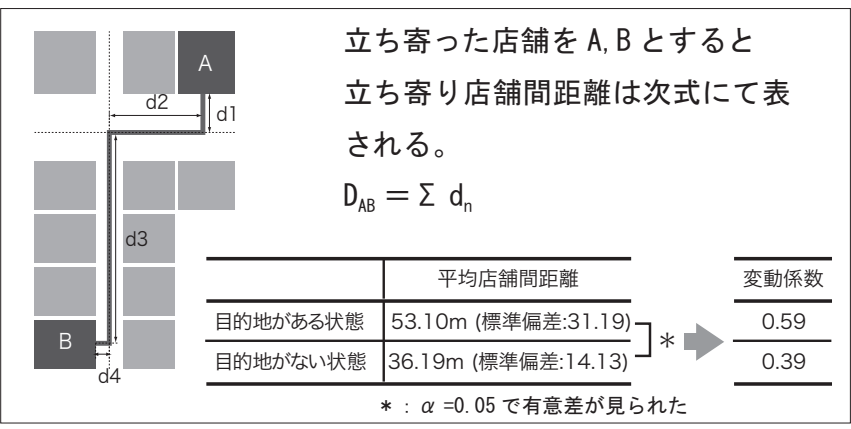

図 4 状態別立ち寄り店舗間距離

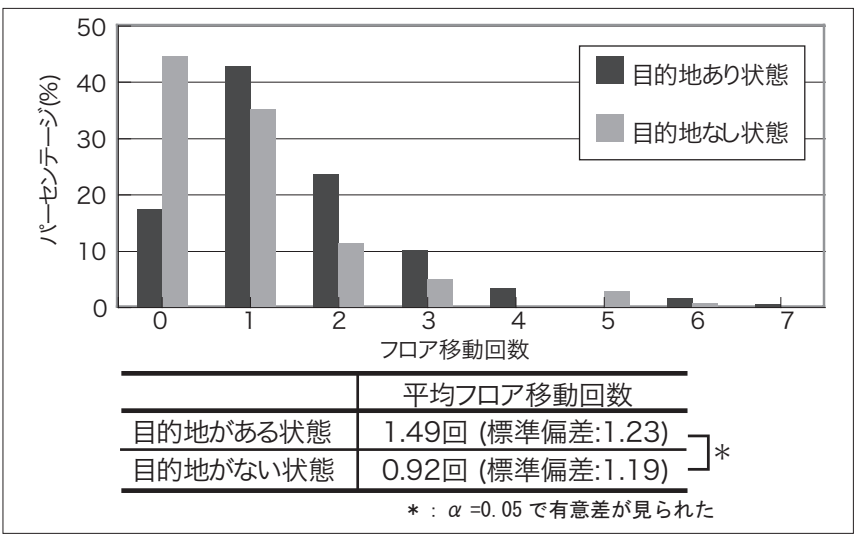

図 5 状態別フロア移動回数

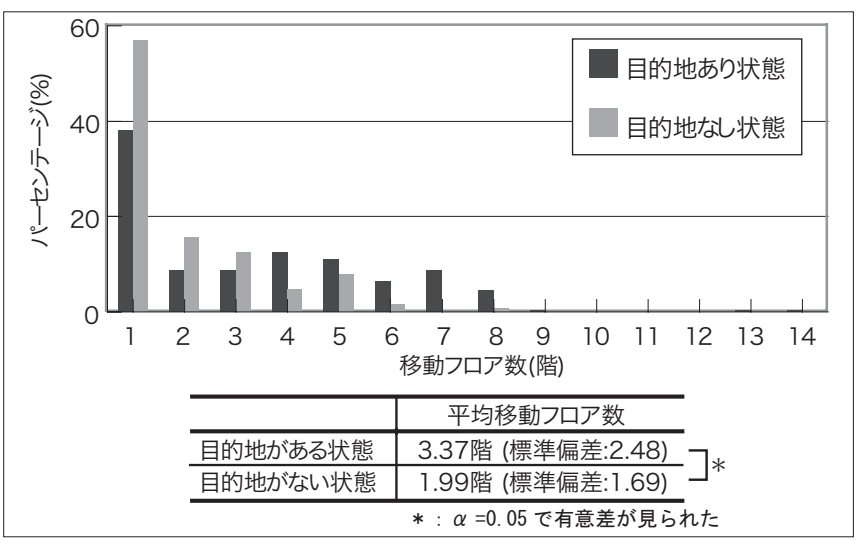

図 6 状態別移動フロア数

に立ち寄りやすい特性がみられる。

「初期状態」の違いでは、立ち寄り店舗数に関しては、初期状態が 「目的地がある状態」の時は、目的的な買い物が多く見られた。初期 状態の割合は、「目的地がある状態」の方が大幅に高く、立ち寄り店 舗数は初期状態が、「目的地がない状態」の方が多く、また滞在時間 も長い。

目的地がない状態の時は、同一フロア内で移動しやすく、フロア 移動がある場合でも 1 フロア分の移動の割合が高かった。

5. 買い物行動シミュレーション

5. 1 モデルの検討

買い物行動の再現を試みるシミュレーションを行うために、4.の 


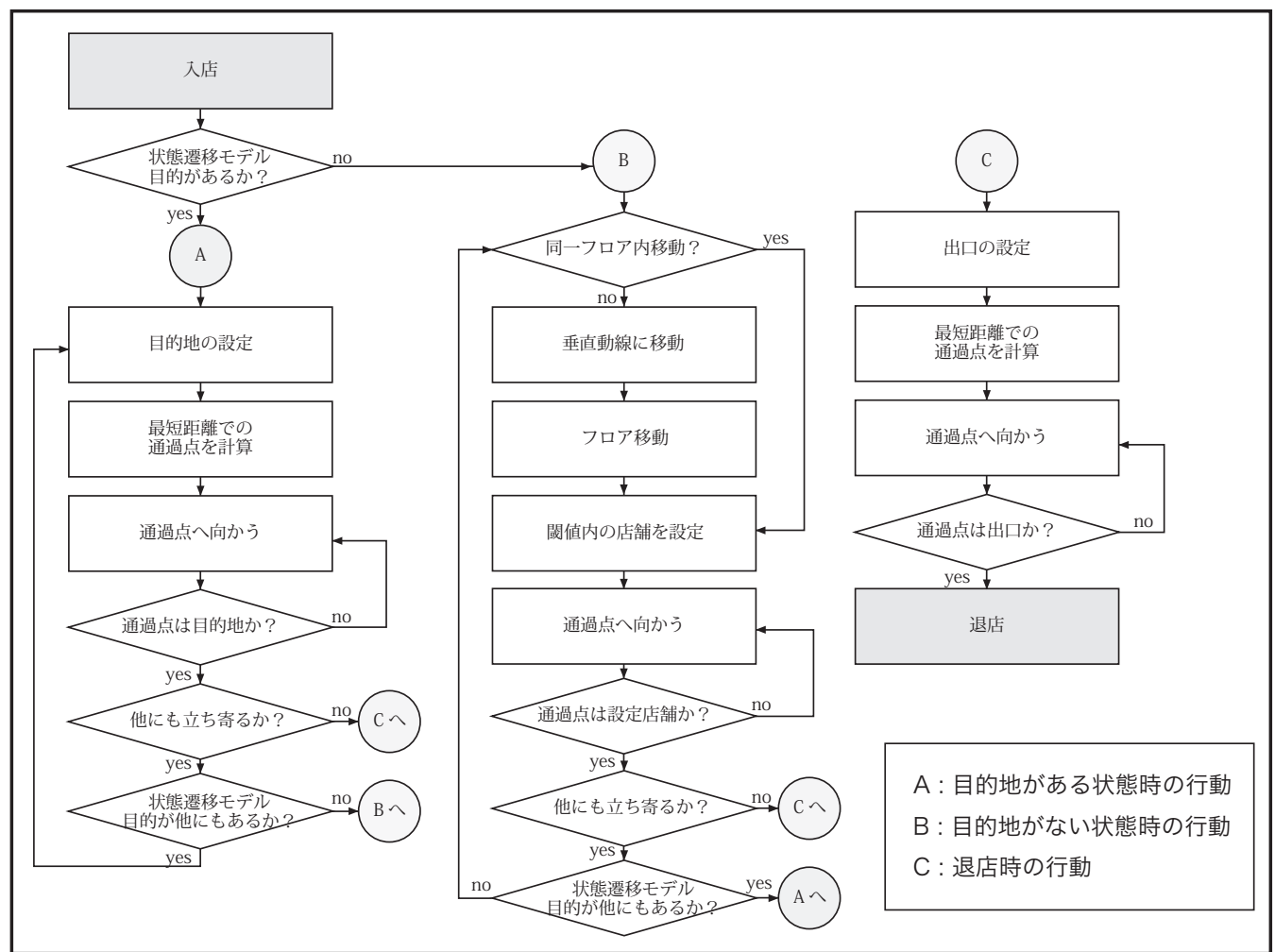

図 8 モデルのフロー

結果で得た知見をふまえて、2つの状態と、それに応じた行動特性を、 次の $\mathrm{a} \sim \mathrm{g}$ の手順でモデル化した。(図 7 ) 注3

a. 買い物客は、初期（入店時）には、図 2 の割合に従って、目 的がある状態か、目的がない状態か、その割合に従って発生。

b. 買い物客は行動を開始し、店舗に立ち寄るごとに、2つの状 態を 4.1 での状態遷移確率に従って遷移する。

c. 立ち寄り店舗数は、入店時の状態「初期状態」によって設定し、 4.2 の分布に従う。

d. 目的地がある状態の時にはシミュレーション上では、ランダ ムに目的地を設定することとし、その行動は、最短経路で設 定された目的地に向かう。

e. 目的地がない状態の時には、 4.3 での立ち寄り店舗間距離をし きい值とし、その範囲内にある店舗に立ち寄る。

f. 目的地がない状態の時のフロア移動の割合は、4.4の結果によ る。

$\mathrm{g}$ 設定した立ち寄り店舗数だけ、すべて立ち寄りを終えて、条件 をすべて満たした後は、最終状態である退占状態に遷移し、 目的地を出口に設定して、最短経路を選択しながら行動し、 退店する。

以上のように、人間のモデルは個々の人間が、状態を変化しながら、 目的地に向から事を表現する事ができる、「個人型」モデルを採用し、 また、空間のモデルは大規模でかつ、店舗全体の系を検討するのに 適した、「ネットワーク型」を採用した注 4 。空間モデルでは「店舗ノ ード」、「通路ノード」、「垂直動線ノード」を定めて、それぞれをリ ンクで結んだ。モデルのフローを図 8 に示す。

\section{2 シミュレーションモデルの検証}

シミュレーションモデルの再現性を確かめるために、モデル作成 に用いた調査を行った場所とは別の商業施設を選定し、実地調査を 行い、館内数力所における通過人数と、シミュレーション結果の比 較により、検証を行った。

混雑による行動の選択への影響を避けるため、断面交通量調査は平 日に行った。

場所：都内大規模商業施設 $\mathrm{L}$

(店舗面積 $62,000 \mathrm{~m}^{2} 、$ 商業部分は 3 フロア)

日時：2008 年 12 月 11 日（木） 13 時〜 15 時

対象：調査場所の全買い物客

内容 : 館内の 22 力所で、各 5 分間断面交通量（2回の平均） シミュレーション用に上記調查場所の空間について、ネットワーク モデル化を行った。モデル空間を作成するにあたっては、図 9 のよ うに 335 個の node エージェントを配置した。シミュレーションでの 1step を 1 秒として捉え、スタート時は全員入口から発生して、し ばらくして、買い物客が広がることを考慮するため、シミュレーシ ヨン開始から 700step から 1000step までの 300step、つまり 5 分間 の值での通過人数をカウントした。

これらの、調査による実測值と 10 回のシミュレーションから求め た平均值を比較した結果が図 10 である。この図のデータについて、 相関性の検証を行ったところ 0.816 であり、正の強い相関が見られ た。これにより買い物行動のシミュレーションモデルとして精度の 高いものが得られたといえる。

\section{6. シミュレーターの適用}

本シミュレーションを適用して、プランの検討を行った。眓 11 に は、中層タイプの 2 案の比較結果の例を示した。これは、設計エス 

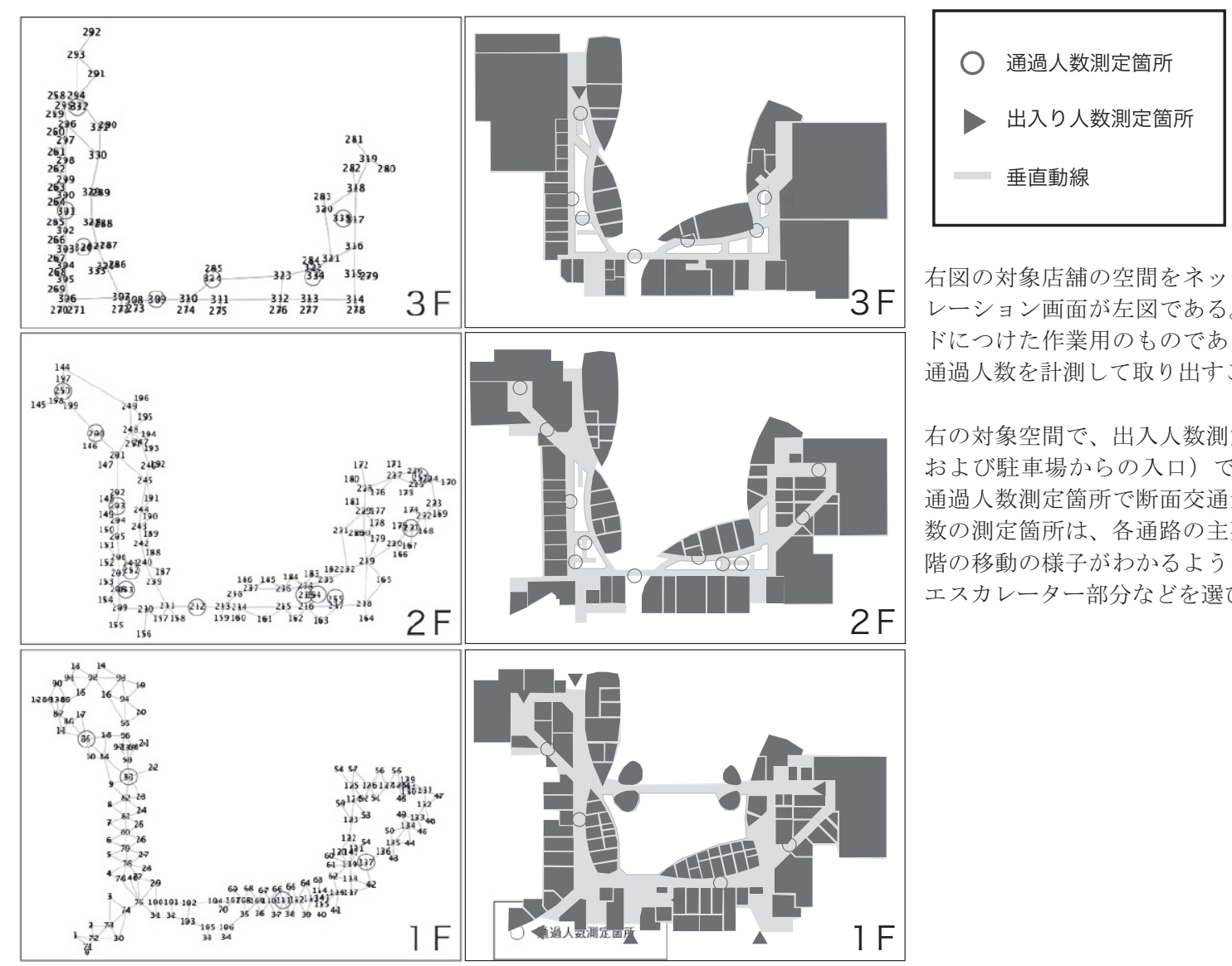

右図の対象店舗の空間をネットワーク化したシミュ レーション画面が左図である。左図内の数字はノー ドにつけた作業用のものであり、このノードごとに 通過人数を計測して取り出すことができる。

右の対象空間で、出入人数測定箇所（すべての入口 および駐車場からの入口）で、入り人数を計測し、 通過人数測定箇所で断面交通量を計測した。通過人 数の測定箇所は、各通路の主要な箇所、および上下 階の移動の様子がわかるように、移動動線のメイン エスカレーター部分などを選び計測した。

図 9 シミュレーション画面（左）と実測箇所（右）

キースの段階や、改装や模様替え、主動線の変更などにも適用でき ることを示す。その他、高層のプラン 2 案の比較などでは、「入口位 置と館内の上下階での偏り」や「垂直動線の平面上での位置のちがい」 により、各階平面上での偏りなどを見ることが可能となった。

また、各プランでの館内での行動の特徴として、「店舗間歩行距離」 を、目的地がある状態、および、目的地がない状態ごとに分けて集 計することができるので、それらの違いを分析し、ぶらぶらとウイ ンドーショッピングをすることに向いたプランか、あるいは、歩行 距離が短く効率的に買い物に回れるプランか、どちらに適したプラ ンであるかもわかる。

\section{7. まとめ・展望}

本論では、日本の大型商業施設で買物行動を追跡し、買物行動の実 態と行動の特性を明らかにした。その上で、

\section{・目的地のある状態・目的地のない状態}

の 2 つの行動状態により経路選択の仕方が異なる、行動モデルを作 成した。この行動モデルには、今回のような調查データから得られ る数字を用いて、初期 (入店時) の状態設定、状態の遷移、フロア 移動の行動発生確率などを組み込むことが可能になった。一方、空 間モデルは、「店舗ノード」、「通路ノード」、「垂直動線ノード」をノ ードとして、それらを繋いだネットワークモデルとした。空間モデ ル上で、行動モデルに従ってシミュレーションを行なった。このモ デルによるシミュレーション結果を、実空間での調查結果により検 証し、再現性の高いモデルが得られたことがわかった。

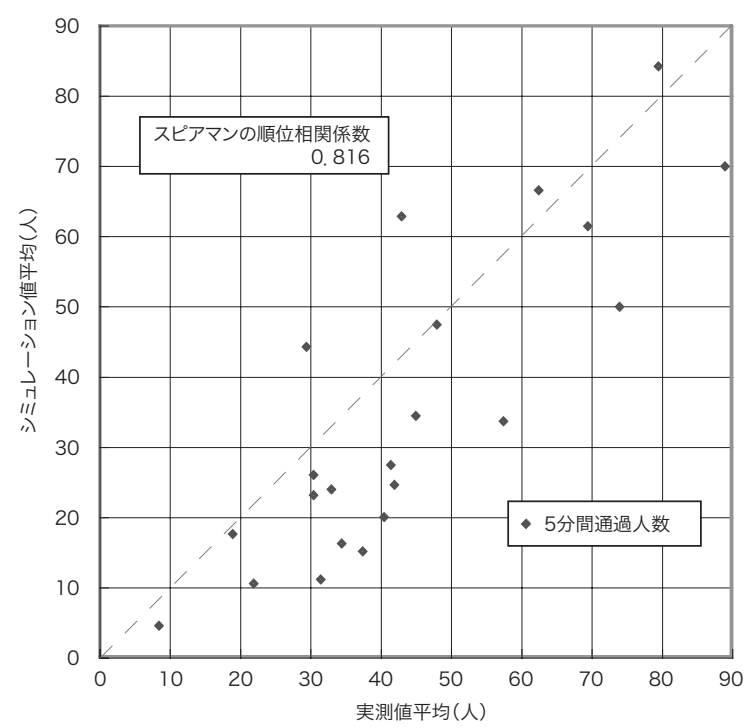

図 10 実測值とシミュレーション予測

本システムによって、避難行動などのような一つの目的へむかって 動くモデルとは異なる、買物行動のように目的地が多様で、時系列 的に状態が変化するような一連の行動を、再現することができた。

特に、空間モデルをネットワークで表現したことによって、売り場 などの平面詳細が確定する前の、設計初期のエスキスでも十分に有 用であること、また垂直移動の行動特性を含み、多層階の建物の検 討に利用できると考えられる。

調查では、各店舗の内容と、そこが目的地化しやすいかどうかなど も、ある程度傾向が把握できたが、本モデルの目的は設計初期段階 


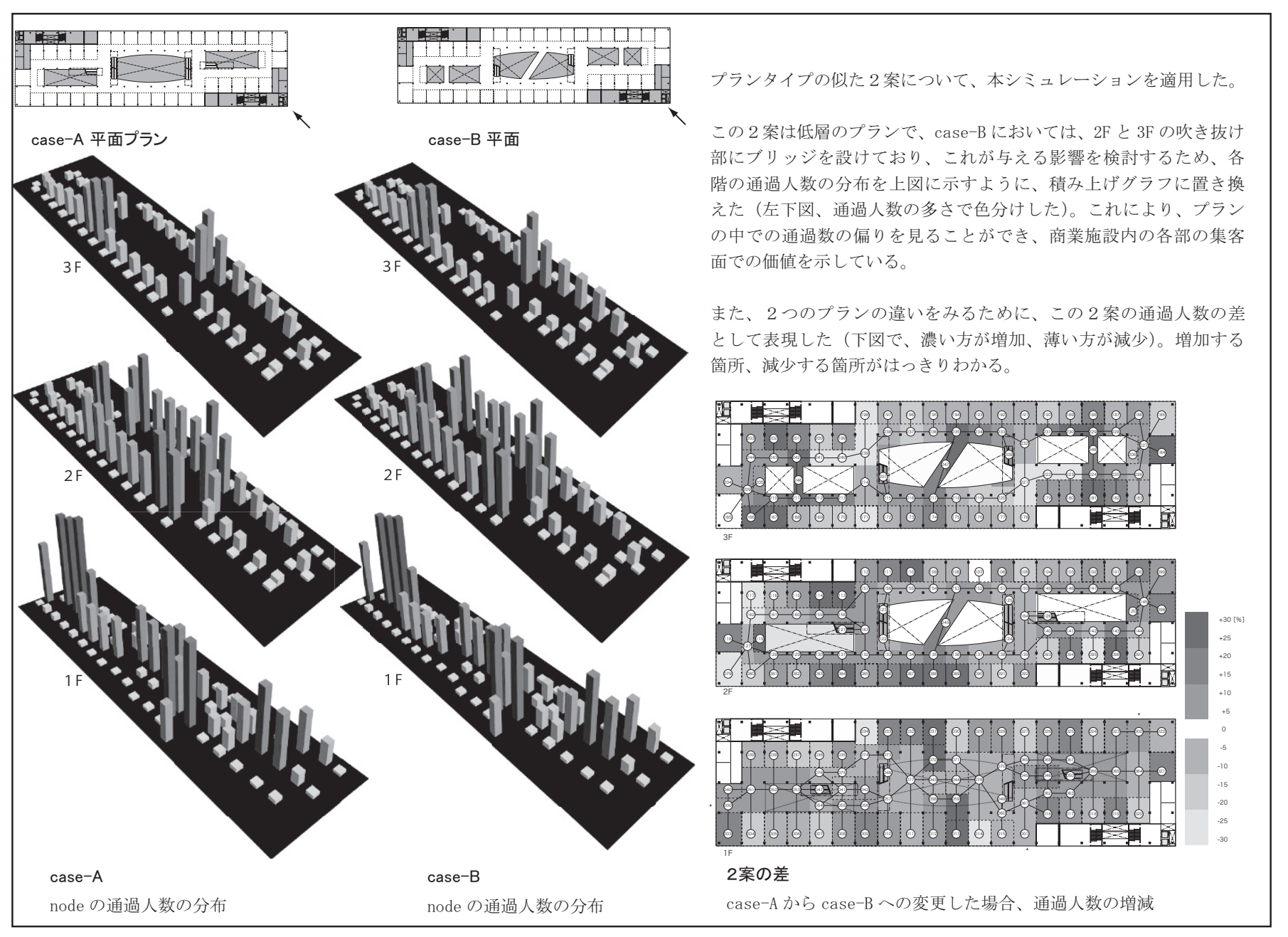

図 11 シミュレーション結果の例 (中層タイプの比較)

でのモデルであり、商業施設の設計段階では入るテナントの種別や 集客力などは、確定していないのが実情である。そのため、純粋に 空間的なつながりと時間変化による行動特性を中心としたモデルと なった。結果として各状態の人が、どの場所を通過しやすいか、と いった局所的な集計も可能であるため、設計段階のみならず、テナ ントの種別や、運用が始まってからの制御や誘導にも利用できると 考えられる。今後、多様な顧客ニーズによる、より細かいサービス 面で利用する場合には、重み付けや、属性別の傾向などを組み込む とよいと思われる。

今後の課題として、行動調査データを増やし店舗による特徵を明ら かにし精度を高めることがある。またマルチエージェントシステム が得意とする、他者の影響や建築空間構造が状態の変化に与える影 響なども示す事ができるようなリアルタイムでの検討モデルや、さ らに、各店舗での滞在時間や休㮩行動などと言った厳密なモデルを 組み込む事により、充実した買い物行動を示寸事が期待される。また、 規模に応じた店舗滞在時間の決定モデルや、昼食時のような特定行 動、あるいは疲労などにともなう休輴行動など、が、今回の基本的 な行動モデルに加わって詳細なモデル化を行うことが期待される。

\section{参考文献}

1）田中壮作，林田和人，渡辺仁史：大規模商店舗に抢ける入館時歩行行
動モデルに関する研究, 日本建築学会 大会学術講演梗概集, E-1 分冊, pp. 893-894, 2005

2）小島尚人，後藤信，高柳英明，服部岑生 : 大規模小売店舗におけるマク 口流動制御手法に関する研究 その 1 利用客行動調查とモデル構築につい て, 日本建築学会大会学術講演梗概集，E-1 分冊，p. 491，2006

3）阿部武彦, 山田健司, 石井和克, 中本義徳, 木村春彦：マルチェージェン 卜を用いた小売店レイアウト支援システム, 電子情報通信学会総合大会講演 論文集, p. 8, 2006

注

注 1) 観察者がスタート地点に到着して、開始を決めて観察を開始し、3人目 に入店をした人などと決めて無作為に追跡者を選定した。

注 2）行動状態の調查は、「目的地のある状態」「目的地のない状態」を仮定し て、トラッキング（追跡）調查により、対象とした客が館内の各所でとっ た行動の詳細、たとえば見たもの（看板や店）購入したもの、手に取った もの、歩行速度の変化、買物をどれくらいしたのか、などを総合的に判断 して、どうちらの行動状態にあるかというデータを得た。また一連の行動 の終了後、全体の行動より、状態について再度判断をする部分もあった。 「買い物」中には、店舗での買い物をすることで、一定の目的を果たし、状 態が変わる場面があると考え、店舗到達ごとに状態を確定してデータ化して いる。実際には心理的な状態変化が起こり、店舗の間で変化がみられたたケ 一スもあったが、本調査においては観察から、どちらか優位な方に 1 つに定 めて集計を行った。

注3) シミュレーション環境には (株) 構造計画研究所による artisoc を用いた。 注 4）人間のモデルとしては、「個人型」モデルの他に「群衆型」があるが状態 の違いが記述できる「個人型」を採用した。空間のモデルには「ネットワー ク型」の他に「座標型」「メッシュ」がある。計画初期段階の検討につかえ るよう、空間についてはネットワーク型を採用している。 